\title{
活魚（試料ヤマメ）の超音波反射について
}

\author{
佐野典達 \\ (1974 年 2 月 26 日受理)
}

On the Reflection of Ultrasounds from a Living Fish, Yamame

\section{Noritatsu SANO*2}

In relation to the measuring of the reflection of ultrasounds from a fish, we have taken accurate measurements of the relationship between the swimming action and the reflection of ultrasounds, as made by the living fish, Yamame.

The echo sounder used was a $50 \mathrm{KHz}$ ultrasound echo sounder, a directional projector having a $30^{\circ}$ effective beam angle and a hydrophone having a $110^{\circ}$ of beam angle.

These experiments were made inside an anechoic tank. The dimensions of this tank were $200 \mathrm{~cm}$ long, $140 \mathrm{~cm}$ wide and $140 \mathrm{~cm}$ deep.

The measuring method was as follows:

The swimming actions were measured by a dynamic strain gauge in connection with a U-gauge. A practical method is to use a reference target of known reflection loss (steel ball), placed at the same range as the unknown, and to compare the levels from the reference target and the living fish to be measured.

The acoustic back scattering polar diagram of living fishes or anesthetized fishes could be obtained by measuring the echo level from the fish in all directions at intervals of $10^{\circ}$ on the lateral plane.

The results obtained are summarized as follows:

1) There was little relationship between the swimming action and the echo level from a living fish, even though it may be obtained by the same aspect of living fish.

2) On the polar diagram, the directions of maximun echo level are of a lateral aspect.

3) We found little change in the echo level of the dorsal aspect.

サヶ・マス漁業で, 魚群探知機の使用が演場の探知・選択から資源量の把握のための必ずしも有効な手 段・方法に現在なつていない点については，技術上に問題点がある。この操業上または調查・研究上に括诘 る魚探技術の諸問題点について，その若干はすでに報告した ${ }^{1,2,3)}$ 。

筆者は，サケ・マス用垂直・水平方向魚探で取得した鮮明なサケ・マスのエコー・パターンから魚種の識 別, 魚群量, 捿息状態などの生物学的, 資源学的諸問題を解析する目的で，二三の実験老試みてきた。

今回の実験の目的は，サヶ・マス漁場でサヶ・マスが自然環境下で悽息する状態を実駼水慒の中に再現し， これに超音波が入射した場合複雑な生物と環境のかかかりあいのなかで起きる超音波の反射現象を観測する といらことではなく, 可能な限りこの現象を単純な要因に分解して測定を繰返し, 定性・定量的に反射機挜 を解明すると同時に，サケ・マス魚探技術を改善することにある。したがつて, 超音波の反射量をより精確 に測定するために無響水槽を使用した。この水槽中でサケ・マスを実験対象として反射量を測定することは 水槽の大きさの関係で困難なので，活魚の試料としてヤマメ(Oncorhynchus masou f. ishikawai) を選び，

*1 1973 年 4 月 3 日, 日本水産学会で発表。

*2 北海道大学水歷学部 (The Faculty of Fisheries, Hokkaido University, Hakodate Japan) 
この魚体からの超音波の反射現象, とくに魚体の遊泳運動の測定, さらに遊泳運動を瞬間的な魚体形状の連 続的変化と見做し，それに入射した超音波の反射量を測定し，活魚の遊泳運動と超音波の反射量について考 察し検討を加光たので以下に報告する。

\section{実 験 方 法}

測定装置 木製の音響挪（寸法，四角柱部 $5 \times 5 \times 5 \mathrm{~cm}(\mathrm{~L} \times \mathrm{B} \times \mathrm{H})$ ）角錐部 $5 \times 5 \times 13 \mathrm{~cm}(\mathrm{~L} \times \mathrm{B} \times \mathrm{H})$ ) を 六面にうめ込んだ実有効容積 $1.8 \times 1.4 \times 1.4 \mathrm{~m}$ の木製無響水槽の一端に, $50 \mathrm{KHz}$ 用超音波送波器および受 波器を水深 $68 \mathrm{~cm}$ のところに設置し, 音源 (送波器) から $70 \mathrm{~cm}$ 離れた位置に目標物であるヤマメを保持 できるように, 水槽上面に広さ $70 \times 60 \mathrm{~cm}$ の測定のための音響揳をらめ达まない部分を作つた。超音波ビ 一ム幅は, 指向半減全角 $30^{\circ}$, パルス幅 $0.5 \mathrm{~m} \mathrm{sec}$, 受波器は指向半減全角 $110^{\circ}$ で, 反射波拈よび散乱波 を可能な限り受信できるよう設計した。反射波は, シンクロスコープで波形観測，写真撮影および抵抗減衰 器で反射音圧の反響余裕值 (マージン $\mathrm{dB}$ ) の測定を行なつた。

観測対象を活魚 (ヤマメ) の遊泳運動とするので, 魚体の遊泳力を動丕計で張力に变換し自記記録計に記

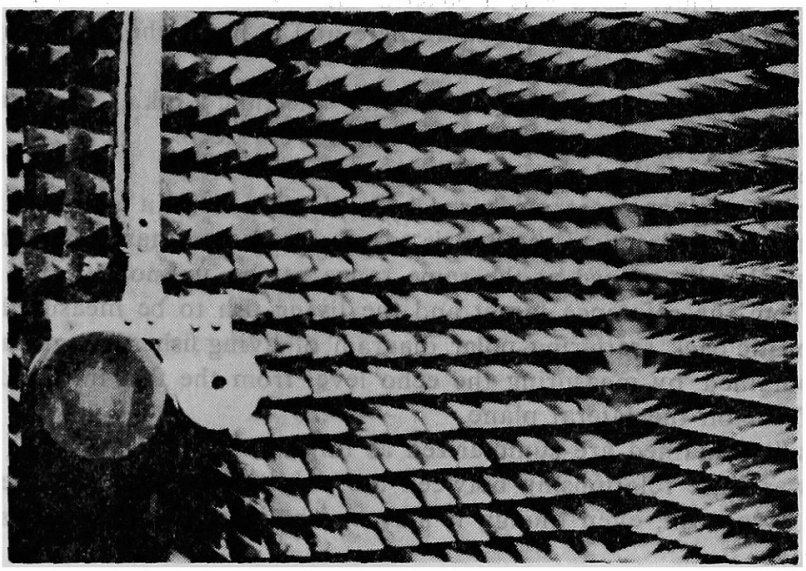

Fig. 1. View of the directional projector and hydrophone mounted on an anechoic tank.

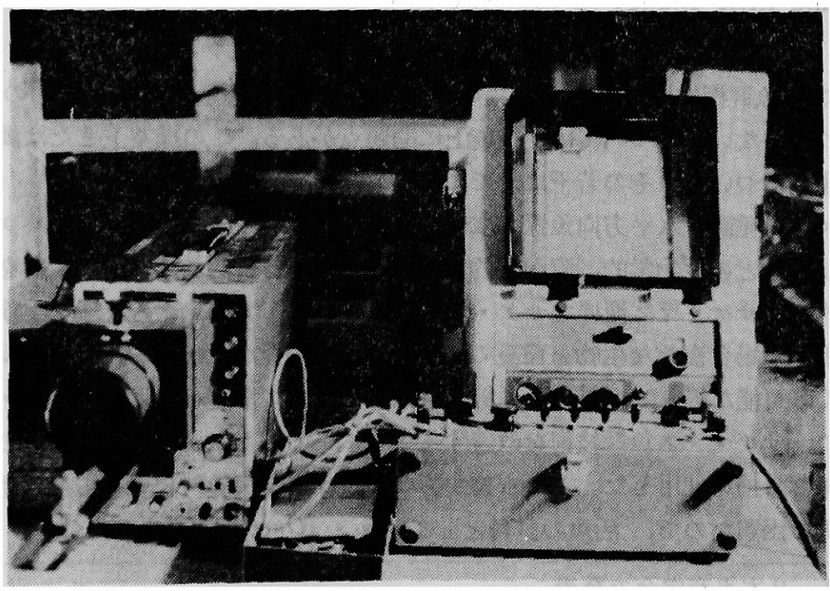

Fig. 2. Arrangement of measuring apparatuses. 


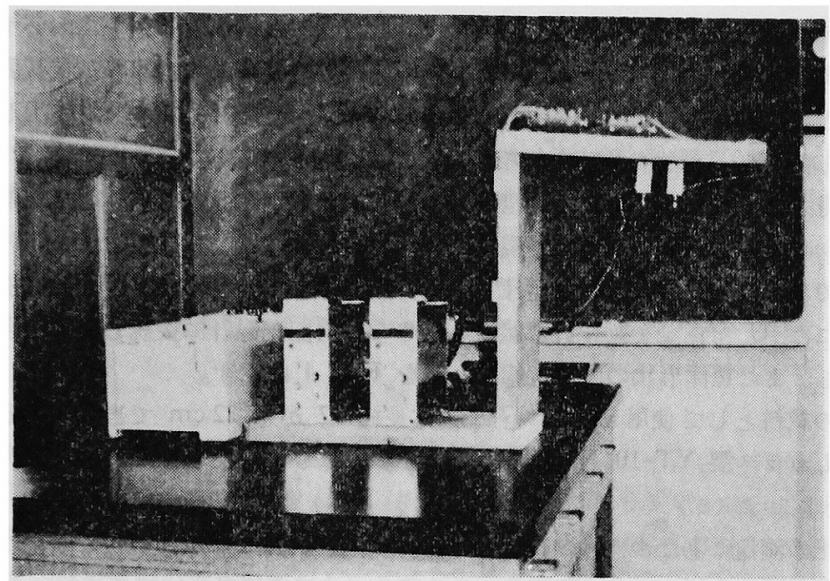

Fig. 3. Array of dynamic strain gauge used in measuring the swimming action.

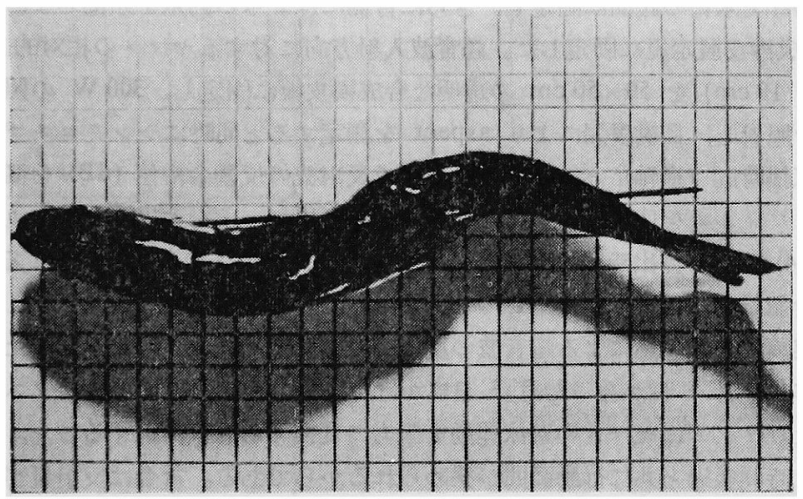

a) common swimming

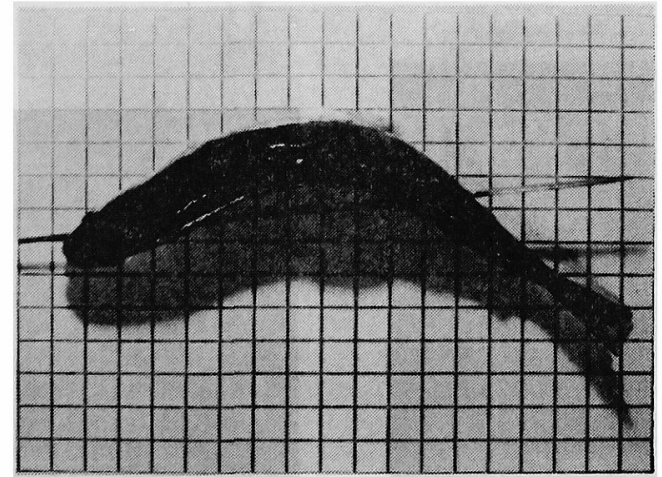

b) fast swimming

Fig. 4. Form of anesthetized fish used in measuring the echo level or reflection loss. 
録させる。一方遊泳に伴う魚体形状の変形については, 麻酔をかけスケール板上に批いて変形状態を写真で 判定した。また, 測定時に信るる測定装置 (超音波発振器, 送受波器, 增幅器, 抵抗隇衰器, シンクロスコ ープ，無響水槽など）の安定性をチェックするため，常隹鉄球（直径 $3.75 \mathrm{~cm}$ ) を使用して反射音压に変動 がないことを確認してから目標物の測定を行なつた。超音波の入射方向に対するヤマメの相対的方位 (aspect）および位置関係は，目視钼測により水槽上面に設置した全円分度器で測定した。無響水槽に設置した 送受波器を Fig. 1 に, 超音波測定装置の概観を Fig. 2 亿示す。

測定対象が活魚であるため反射音圧を測定するとき, 影響を与息るであ万ら遊泳力は張力に变換して定量

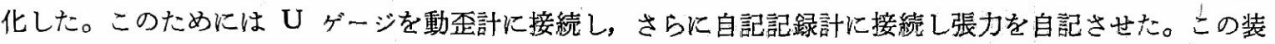
置を Fig. 3 に示し，京心魚体形状の変形状態の一例を Fig. 4 に示す。

測定方法 活魚の試料として使用したヤマメは, 体長約 17 から $22 \mathrm{~cm}$ で当学部・七飯養魚施設から一 回に数星ずつ運搬しガラス製 YT-10 号の飼育水槽で水温叔よび慨料を管理しながら，実鈳に供するまで飼 育した。

超音波の反射音圧の測定にあたつては，1）遊泳運動による影響，2）魚体形状の変化による影響の場合に わけて実験を実施した。

1) の実験において, まず予備的に超音波ビーム中からヤマメが遊泳し逃出しないよう音源から距離 $70 \mathrm{~cm}$ のところに, 約 $50 \mathrm{~cm}^{8}$ の範囲を自由に遊泳できるよ5太さ 8 号のテグスに 6 番の釣針をつけた釣糸を, ヤ マ×の腹側に 1 本つけて水槽の底面に固定し，さらに背側には 2 本の釣系を頭部拉よび尾部につけて水面上 で aspect 測定用合成樹皮製定規に固定した。超音波入射方向に対するヤマメの相対的方位は， aspect 測定 用全円分度器（直径 $18 \mathrm{~cm}$ ) $50 \times 50 \mathrm{~cm}$ の透明な合成樹皮板に固定し， $300 \mathrm{~W}$ の照明用ラシプ 2 個で無 響水槽中のヤーマメ照射し，目視観測により aspect を測定すると同時にシンクロスコープで反射波形の最

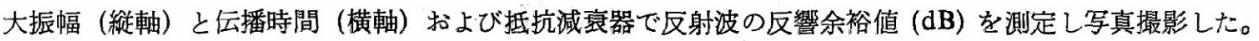
写真は $35 \mathrm{~mm}, \mathrm{SS}$ フィルムを使用，シンクロスコープ撮影用フードを使用しデータカードを記入した上装 備し, レンズ (F 1.4) 開放, 露出時間 1/2 sec とした。これはヤマメの遊泳運動による反射波形の変動 ( コーのパターン）を記録するためでありこの一例を Fig. 5 に示す。1970年 11 月 10 日から同月 25 日 まで実施した予備実験で遊泳運動による超音波の反射音圧を測定できる見通しができた。

本実験は 1971 年 11 月 5 日から 12 月 3 日にかけて実施したが，この場合テグスのかかりに 26 番の 細い、針金を使用した。テグスはヤマメの遊泳運動を張力に変換するとき伸縮すること，および自由に泳ぎょ わるので撚りが入り時間経過と共に行動範囲が㹧められるからである。針金は反射量が僅少であることを確 認した上で U ゲージに，さらに動雨計を接続し張力を測定した。ヤマメの aspect は人為的に制御不可能 なので多数回測定した。

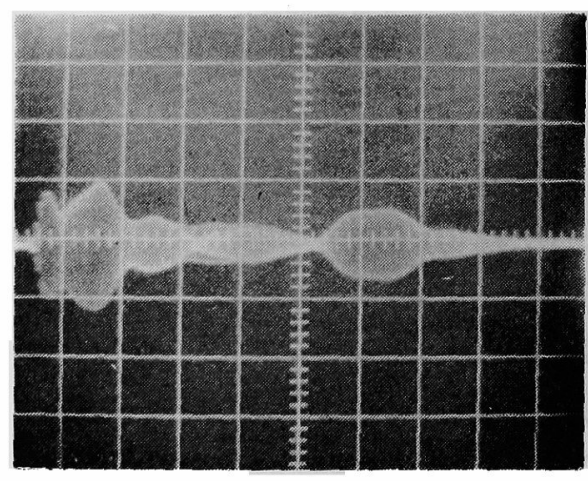

a) swimming action

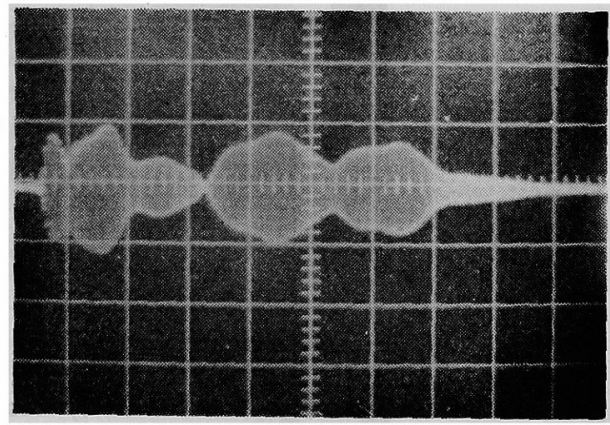

b) fast swimming 1

Fig. 5. Photographs taken by syncroscope showing the echo waves of the living fish. 
2) の実験において，ヤマメは麻醉薬 (NS 222) の稀釈液で 3 分から 5 分間麻醉させた後，魚体形状を变形 しその状態を維持するために鉄製の“くし”（直径 $2 \mathrm{~mm}$, 長さ魚体長より短かいるの) を尾びれから替椎骨

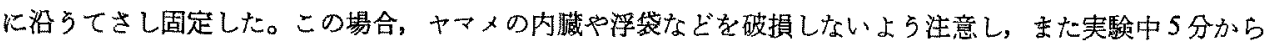
10 分間位で麻醉からさめて動きだすこともあるので，その場合には直ちに取上げ飼育水楷で 数時間休息さ せたのち，再度麻醉をかけて測定した。ヤマメの側面方向では, aspectを $10^{\circ}$ 毎炕 $0^{\circ}$ から $360^{\circ}$ まで一 回転し測定に要す時間法 11 分から 52 分であり，背面方向の場合は $90^{\circ}$ 每に回転し测定所要時間は. 5 分 以内であつた。な扣鉄製くしも反射音圧は菌少であることを確認した。ヤマメの魚体形状の变形状態は， Fig. 4 a) の普通前進遊泳型，b) の速前進遊泳型飞大別して測定した。

\section{実 䣯 結 果}

超音波の入射方向に頭部が対峙しているとき aspect $0^{\circ}$ とし，それより時計方向に $0^{\circ} ， 30^{\circ} ， 40^{\circ} ， 45^{\circ}$ ， $60^{\circ}, 90^{\circ}, 180^{\circ}, 270^{\circ}, 300^{\circ}$ に aspect を大別し体長 $17.2 \mathrm{~cm}$ のヤマメ（合）を前述の測定方法に従い， ヤマメが各 aspect に位直し遊泳しているとき動歪計に接統した自記記録計の記録紙にマークをつけ，同時 にシンクロスコープで反射波形の写真撮影をしこのエコーの写真から反射波の echo level と反射損失を 算出した。

Fig. 6 の a) K aspect $0^{\circ}$ 拈よび $180^{\circ}$, b) に $60^{\circ}$ および $300^{\circ}$ ， c) に $90^{\circ}$ および $270^{\circ}$, d) に $30^{\circ}$ ，

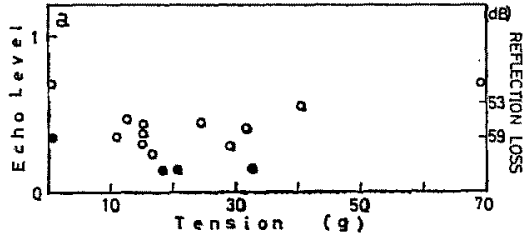

a) aspects $0^{\circ}$ and $180^{\circ}$

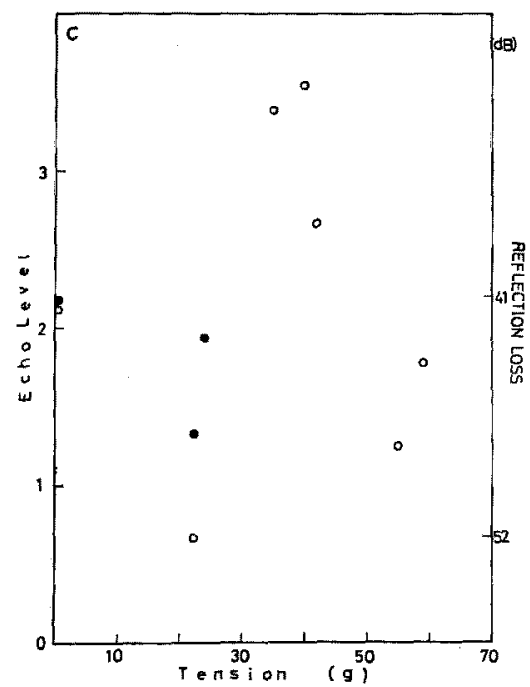

c) aspects $90^{\circ}$ and $270^{\circ}$

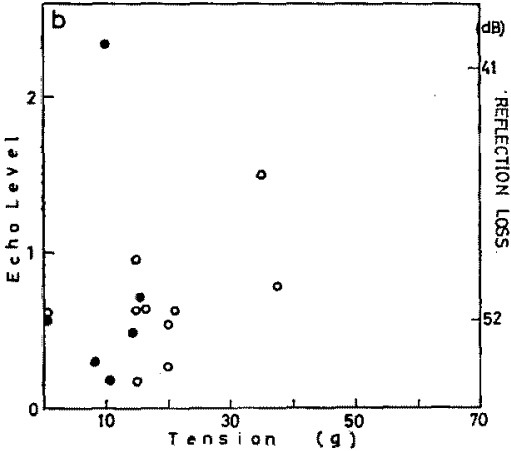

b) aspects $60^{\circ}$ and $300^{\circ}$

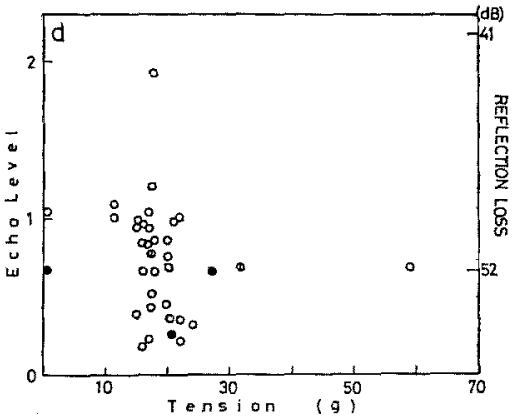

d) aspects $30^{\circ}, 40^{\circ}$ and $45^{\circ}$

Fig. 6. Echo level or reflection loss versus tension for the living fish.

a) $\bigcirc$ aspect $0^{\circ}$, aspect $180^{\circ}$. b) $\bigcirc$ aspect $60^{\circ}$, aspect $300^{\circ}$.

c) $\bigcirc$ aspect $90^{\circ}$, aspect $270^{\circ}$. d) aspect $30^{\circ},(1)$ aspect $40^{\circ}, O$ aspect $45^{\circ}$ 
$40^{\circ}$ および $45^{\circ}$ に括计るヤマ×の遊泳力を示 張力 (g) と相対的 echo level または反射損 失との関係を示す。

Fig. 7 には各 aspect に拈ける echo level の変動筑用をポーラダラフでホすす。マメの echo level $は$, 鉄球の echo level と比敕し理 諭的に計算で算出したいので，一例を示せばヤ $\checkmark \times の$ 相対的 echo level 1.37 社鉄球と此較し 反射損失 $41 \mathrm{~dB}$ に相当する。したがつて， た マメは遊泳運動しておりェコーのパターンが変 動するため反響余裕值の実測は echo level で

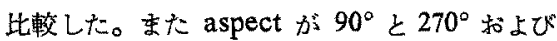
$60^{\circ}$ と $300^{\circ}$ で怯，ヤメの左側面敊よび右側 面から超音波が入射したときの反射波形の状態 を示し，魚体が左右対称であれば echo level は同値である筈であるが寒祭には逆異があつた。 $0^{\circ}$ と $180^{\circ}$ は頭部丸よび星部方向から超音波が 入射したときの echo level を示し, 張力 $0 \mathrm{~g}$ はヤマメが静止している状態を示す。

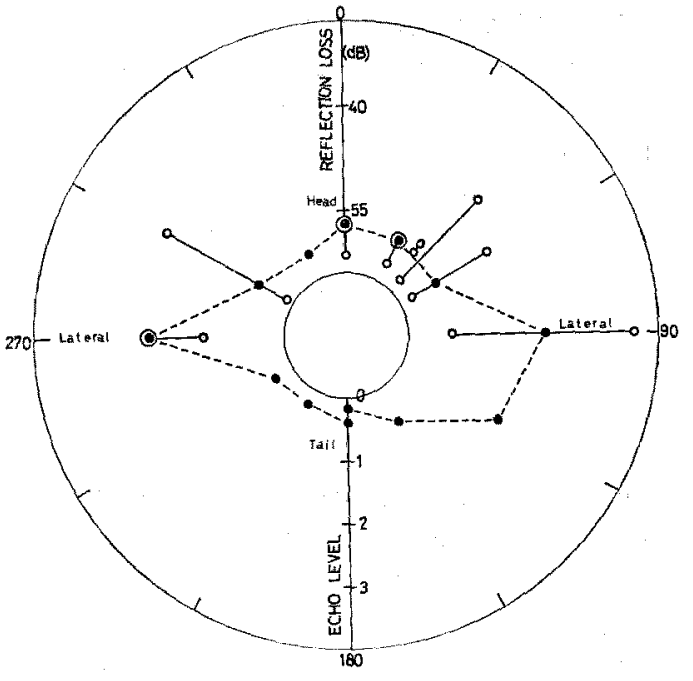

Fig. 7. Polar diagram of living fish on echo level at various aspects.

-.-. tension $0(\mathrm{~g})$

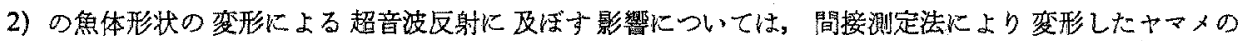
echo level 々鉄球の echo level 支比較し，横軸に aspect, 縱軸に echo level をたは反射損失をプロッ トした。この場合麻酔をかけているので反響余裕值は抵抗減言器で契測可能であり，ヤマメの体長別魚体形 状の変形を二種類に別惊て示す。Fig. 8 a) は体長 $16.9 \mathrm{~cm}$, b) は体長 $17.3 \mathrm{~cm}$, c) は体長 $19.0 \mathrm{~cm}$, d) は体長 $21.7 \mathrm{~cm}$ のヤマメを示し，s.bは鉄球，d は背面方向から超穴波入射したときの echo level を示 す。また Fig. 9 は Fig. 8 をポーラグラフに変換した図である。

体長 $19.0 \mathrm{~cm}$ のヤマメは実験途中で死亡したので速前進遊泳型の実測はできなかつた。

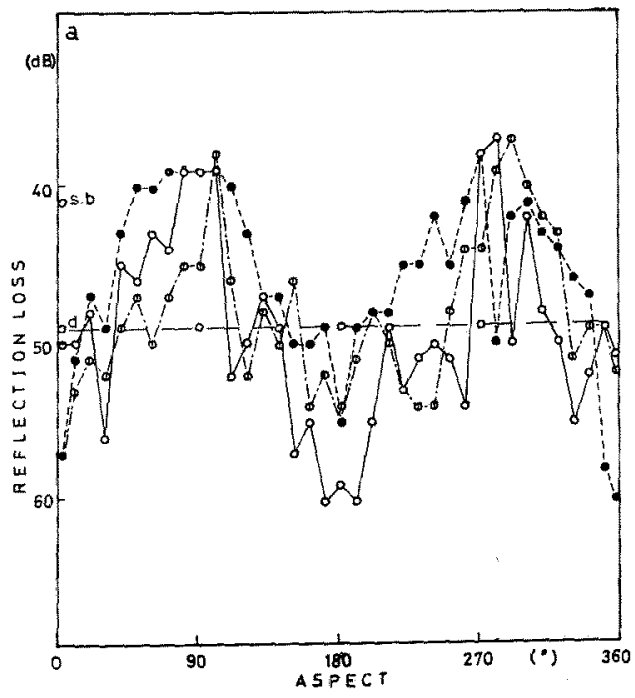

a) fork length $16.9 \mathrm{~cm}$

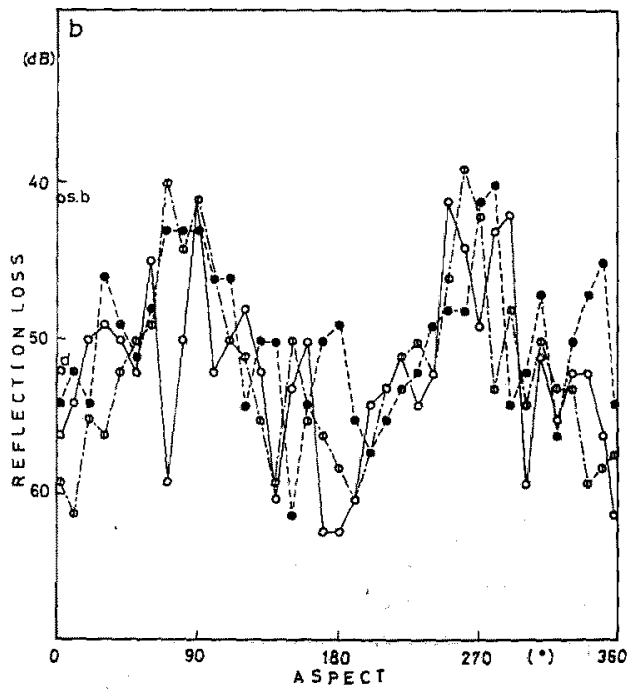

b) fork length $17.3 \mathrm{~cm}$ 


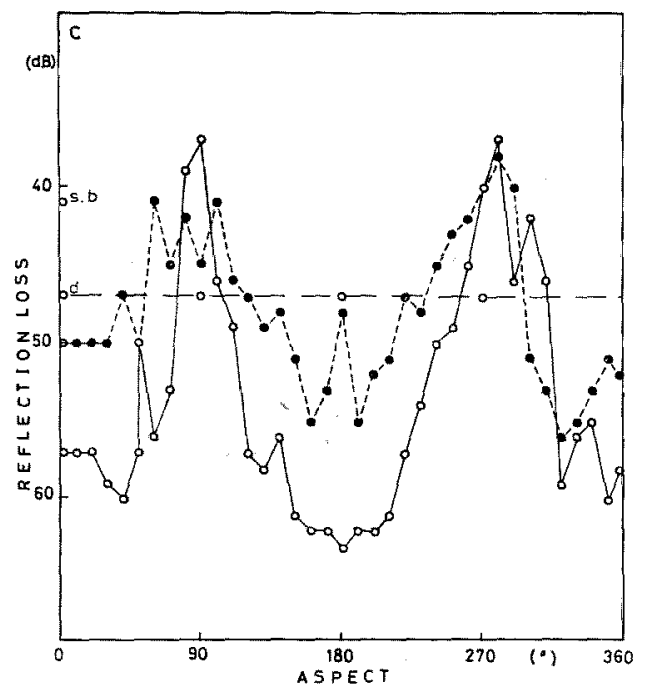

c) fork length $19.0 \mathrm{~cm}$

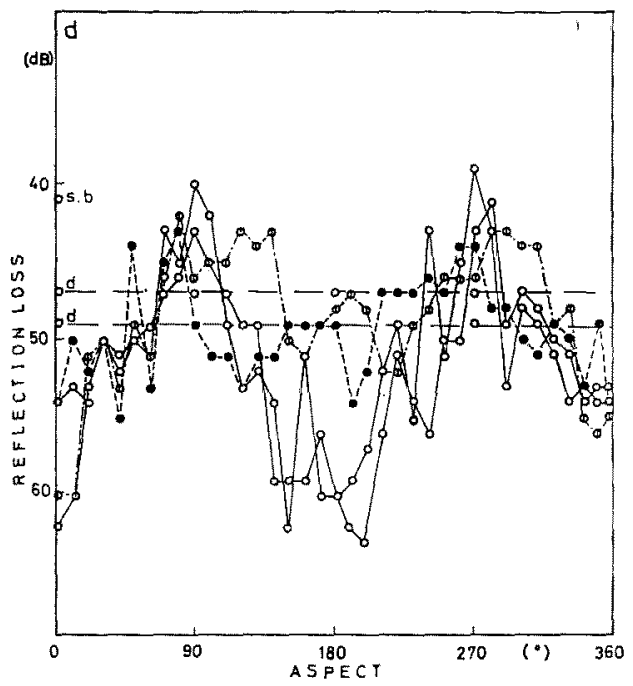

d) fork length $21.7 \mathrm{~cm}$

Fig. 8. Diagrams of echo level versus aspect variations of anesthetized fish. -O- straight, --- (1)-- common swimming, --- fast swimming, os.b steel ball, Od dorsal.

\section{考察と要䄪}

ヤマタの遊泳㖶動時の超音波反射の反響余裕值を瞬間的に寒測することは困嚾なのでンンクロスコーブ上の 写真から echo level を算出する方法を採用した。この方法で取得した結果から，同一魚体同一 aspect で も遊泳運動，つまり張力と超音波反射音肚との間には相関々係ははとんど諗められない。しかしFig. 6 か 5 aspect $0^{\circ}$ の方が (頭部方向から入射), aspect $180^{\circ}$ (尾部方向から入射) と比較して相対的に echo

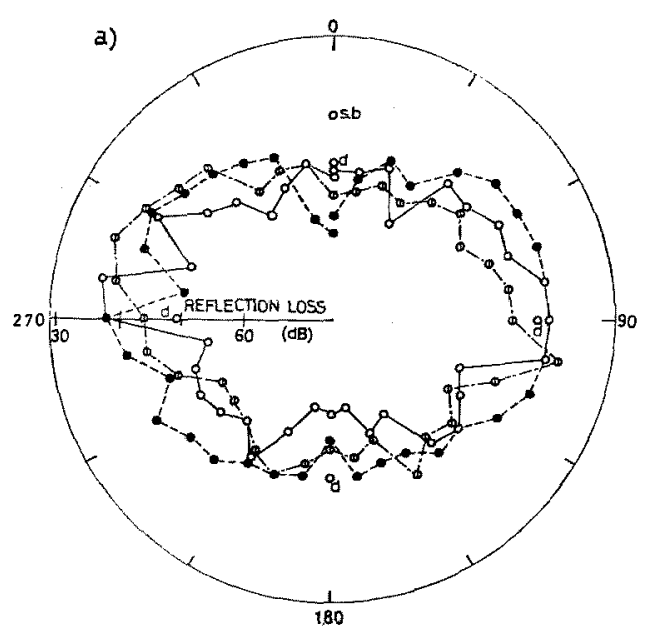

a) fork length $16.9 \mathrm{~cm}$

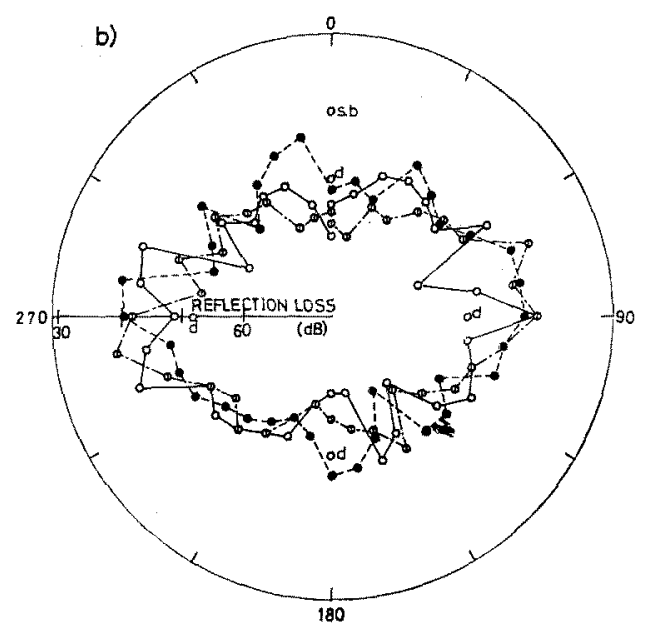

b) fork length $17.3 \mathrm{~cm}$

Fig. 9. 


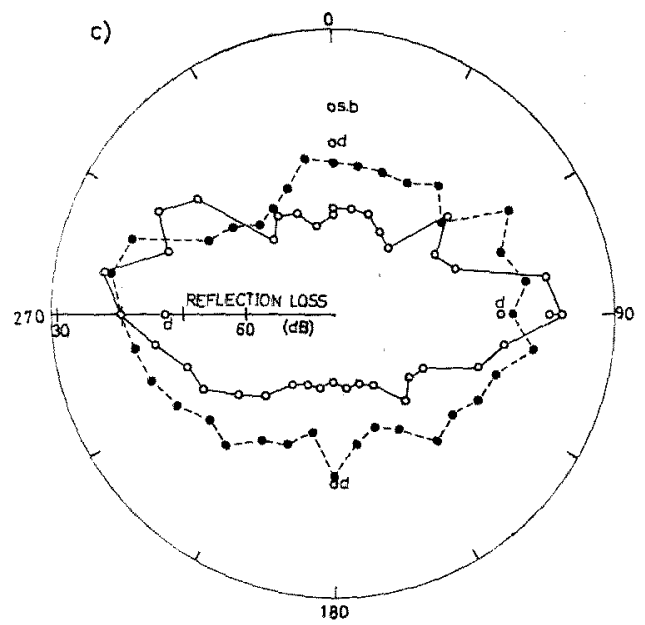

c) fork length $19.0 \mathrm{~cm}$

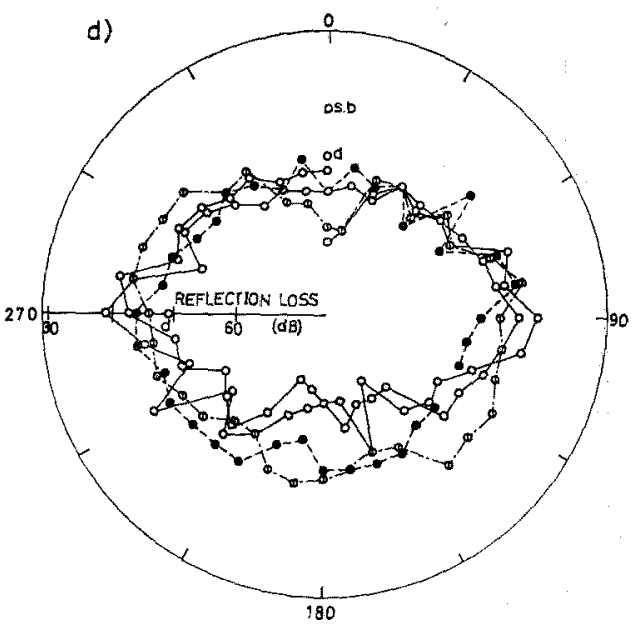

d) fork length $21.7 \mathrm{~cm}$

Fig. 9. Acoustic back scattering polar diagrams of anesthetized fish. -O- straight, -- (D-- common swimming, -..- fast swimming, os.b steel ball, Od dorsal

level は大さかつた。また反射波は張力0の静止状態の echo level を含んで，上下に変動する。この理由 は，遊泳運動することによつてヤマメの体形，超音波入射ビームに対する位置，aspect，魚体周国の水の動 ぎよ゙の变化が複程に相互作用するためであるらと思われる。たた魚体形状の変形にも拘らず，魚体側面か ら超音波入射する場合 (aspect $90^{\circ}$ および 270) 反射に奇与する見挂上の表面積が大さくなる故，したが つて echo level む大きくなるのは当然で左右側面で差異が生ずるのは奏験技術上の原因上考光られる。

魚体形状の变形による超音波の反射に及ばす影響については，ヤマメに麻醉をかけたので反射損失の実測 は可能であつた。しかし実測値には同一魚体で変形させない場合僅少の aspect の変化で反響余裕值の变化 範用が大きく(的 $18 \mathrm{~dB})$ ，また变形することによつて aspect による反響余裕值の変化範因が小さくなる傾

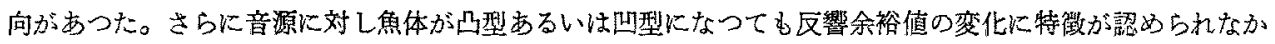
つたが，aspect $0^{\circ}$ および $180^{\circ}$ 方向から超音波入射した場合を比較すると，遊泳運動と同じく就部の方が 反響余裕値が大きく，これは静止した時と同じ傾向であつた。背面方向から超音波入射した場合，aspect の変化による反響余裕値の変化は殆んどみられず，体長と反射損失との間に相関々係認められなかつた。

以上の結果を要的すると, ヤマメの一般的な遊泳運動の強弱と超音波反射量との間に相関々保は認められ ずまた aspect の変化による echo level あるいは反射損失では遊泳運動や魚体形状の変形何拘わらず側 面方向の反射量が大きく，次に頭部，尾部から入射した場合の順に反射量が变動することが確認された。

活魚の遊泳運動と超音波の反射機構の関連を考察する場合, 魚体形状の変形をむ包含するので echo level

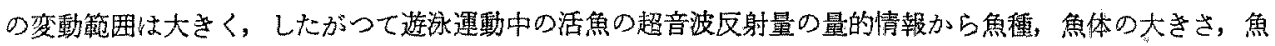
群量など資源状態を適確に把握することは困難であるう。魚探記録像（ニコー・パターン）から，操業上ま たは調查・研究に必要な情垟を取得するには，反射量（エコー）の量的情報だけでは不充分で，必ず対象魚 の生理・生態情埌を併丸得ることにより，さらにエコー・ハターンの量的・質的情報などを総合的に判断す ることによつて魚探技術の改善ができるようになるら。

終りに䠛み，本研究の御指導をいただいた本学部石田教授に謝意を表すると共に，活魚の試料提供に多大 の便宜をあたえて下さつた当学部・七飯俞魚施設久保助教授に潹謝する。 
文

暔

1) 佐野典達: 本誌, 34, 660 669 (1968).

2) 佳野典達: 同誌, 34, 670 680 (1968).

3) 传野典達: 同誌, 37, 1 7 (1971). 